Revista Brasil. Bot., V.31, n.3, p.499-505, jul.-set. 2008

\title{
Biomass and chemical composition of Nitella furcata subsp. mucronata var. mucronata f. oligospira (A. Braun) R. D. Wood (Chlorophyta, Characeae) in the littoral region of Ninféias Pond, São Paulo, Southeast Brazil
}

\author{
NORMA CATARINA BUENO ${ }^{1}$ and CARLOS EDUARDO DE MATTOS BICUDO ${ }^{2,3}$
}

(received: November 23, 2006; accepted: June 26, 2008)

\begin{abstract}
Biomass and chemical composition of Nitella furcata subsp. mucronata var. mucronata f. oligospira (A. Braun) R. D. Wood (Chlorophyta, Characeae) in the littoral region of Ninféias Pond, São Paulo, Southeast Brazil). Temporal variation of Nitella furcata (Roxburgh ex Bruzelius) C. Agardh emend. R. D. Wood subsp. mucronata (A. Braun) R. D. Wood var. mucronata f. oligospira (A. Braun) R. D. Wood biomass and chemical composition were studied at the Ninféias Pond (2338' 18.9” S, 46³7' 16.3” W), a mesotrophic reservoir located in the Parque Estadual das Fontes do Ipiranga Biological Reserve, Municipality of São Paulo, Southeast Brazil. Plants were collected monthly from October 1996 to October 1997 at three fixed stations of reservoir's littoral region. Charophyte biomass spatial distribution pattern did not vary significantly throughout the study period at all sampling stations. As to seasonal variation, the highest average values of the total alga biomass (98.35-266.06 $\left.\mathrm{g} \mathrm{m}^{-2} \mathrm{DW}\right)$ were registered during the rainy season, whereas lowest values $\left(48.86-170.56 \mathrm{~g} \mathrm{~m}^{-2} \mathrm{DW}\right)$ were in the dry season. $\mathrm{P}$ values varied from 23.8 to $225.2 \mathrm{mg} \mathrm{m}^{-2}$ and $\mathrm{C}$ from 139 to $353 \mathrm{mg} \mathrm{m}^{-2}$. During the rainy season, greatest air and water temperature, rain precipitation, turbidity and dissolved inorganic nitrogen values were measured, constituting the best conditions for charophyte growth. Water temperature and nutrient availability in the reservoir played a decisive role towards growth and accumulation of algal biomass.
\end{abstract}

Key words - aquatic macrophytes, biomass, charophyte, chemical composition, Nitella

RESUMO - (Biomassa e composição química de Nitella furcata subsp. mucronata var. mucronata f. oligospira (A. Braun) R. D. Wood (Chlorophyta, Characeae) na região litorânea do Lago das Ninféias, Município de São Paulo, SP, Brasil). Estudou-se a variação temporal da biomassa e da composição química de Nitella furcata (Roxburgh ex Bruzelius) C. Agardh emend. R. D. Wood subsp. mucronata (A. Braun) R. D. Wood var. mucronata f. oligospira (A. Braun) R. D. Wood no Lago das Ninféias (233' 18,9” S, 46³7'16,3” W), um reservatório mesotrófico situado na Reserva Biológica do Parque Estadual das Fontes do Ipiranga, Município de São Paulo, sudeste do Brasil. Coleta mensal de material foi realizada de outubro de 1996 a outubro de 1997 em três estações fixas da região litorânea do reservatório. Com relação à variação temporal, os maiores valores médios de biomassa total da alga (98,35-266,06 g PS m²) foram registrados na estação de chuvas e os menores (48,86-170,56 g PS m²) na de seca. Os valores de P variaram de 23,8 a 225,2 $\mathrm{mg} \mathrm{m}^{-2}$ e os de C de 139 a $353 \mathrm{mg} \mathrm{m}^{-2}$. Durante a estação de chuvas, foram registrados os maiores valores de temperatura do ar e da água, precipitação pluvial, turbidez e nitrogênio inorgânico dissolvido, que constituíram as condições favoráveis ao crescimento das carófitas. Fatores ambientais como aumento de temperatura da água e disponibilidade de nutrientes no reservatório exerceram influência decisiva sobre o crescimento e o acúmulo da biomassa da alga.

Palavras-chave - biomassa, carófita, composição química, macrófitas aquáticas, Nitella

\section{Introduction}

Characeae constitute a unique algal family due to the macroscopic size and highly complex morphological organization of both thallus and gametangia. Although Characeae is somewhat frequent in the littoral region of lakes, creeks and rivers, there is a scarcity of papers, in Brazil and worldwide, dealing with their ecology, biomass, and geographical distribution.

\footnotetext{
1. Universidade Estadual do Oeste do Parana, Caixa Postal 711, 85814-110 Cascavel, PR, Brazil.

2. Instituto de Botânica, Secção de Ecologia, Caixa Postal 3005, 01061-970 São Paulo, SP, Brazil.

3. Corresponding author: cbicudo@ terra.com.br
}

Study on Characeae of lotic environments in Brazil is restricted to those of Vieira Junior et al. (2002, 2003) and Vieira Junior \& Necchi Junior (2002, 2003); and on material from lentic systems to those of Palma-Silva et al. (2002a, 2002b, 2004) and Bueno \& Bicudo (2006). Vieira Junior et al. $(2002,2003)$ are taxonomic papers and dealt, respectively, with the floristic survey of genera Nitella and Chara in lotic systems of the southeastern region of the state of São Paulo. All other eight publications refer to the ecology of members in the family. Thus, Vieira Junior \& Necchi Junior (2002) related the charophyte structure (length of verticillate branchlets and internodes) with the microhabitats from which they were collected. They concluded that longer verticellate branchlets also had longer internodes, whereas Vieira Junior \& Necchi Junior 
(2003) suggested the existence of a high photosynthetic affinity of Characeae for inorganic carbon in the $\mathrm{CO}_{2}$ after studying the photosynthetic characteristics of charophytes from lotic systems in the state of São Paulo. Palma-Silva et al. (2002a) associated clear water with biomass and nutrient variation during the growth of a charophyte stand after a drawdown, in a tropical coastal lagoon (Imboassica Lagoon). Palma-Silva et al. (2002b) studied the role of charophyte primary production in the above same lagoon subjected to human impact. Palma-Silva et al. (2004) approached the charophytes as a nutrient and energy reservoir in the same lagoon above, under anthropic impact. Finally, Bueno \& Bicudo (2006) studied the temporal variation of Nitella furcata (Roxburgh ex Bruzelius) C. Agardh emend. R. D. Wood subsp. mucronata (A. Braun) R. D. Wood var. mucronata f. oligospira (A. Braun) R. D. Wood in the Ninféias Pond, São Paulo State.

This investigation aimed at studying the spatial and seasonal variation of Nitella furcata subsp. mucronata var. mucronata f. oligospira biomass and chemical composition in the Ninféias Pond, municipality of São Paulo, Southeast Brazil.

\section{Material and methods}

Ninféias Pond $\left(23^{\circ} 38^{\prime} 18.9^{\prime \prime} \mathrm{S}, 46^{\circ} 37^{\prime} 16.3^{\prime \prime} \mathrm{W}\right)$ is a shallow mesotrophic reservoir located in the Parque Estadual das Fontes do Ipiranga (Bicudo et al. 2002), municipality of São Paulo, southeastern Brazil. Climate in the area is, according to Conti \& Furlan (2003), tropical of altitude based on the local altitude $(800 \mathrm{~m})$, average of monthly maximum and minimum temperature not surpassing $6-8{ }^{\circ} \mathrm{C}$, and the average precipitation in two months of the year $<60 \mathrm{~mm}$.

Location of the three sampling stations in the pond was defined by the presence of monospecific stands of Nitella furcata subsp. mucronata var. mucronata f. oligospira. Other aquatic macrophyte species (Bacopa sp., Cyperus papirus L., Echinodorus grandiflorus (Cham. \& Schltdl.) Mich., Eleocharis sp., Hydrocleis nymphoides (Willd.) Buch., Mayaca fluviatilis Aubl., Nymphaea ampla (Salisb.) DC., Nitella leptostachys (A. Braun) R.D. Wood var. leptostachys, Ricciocarpus natans (L.) Corda, Salvinia auriculata Aubl., Utricularia foliosa L., Utricularia gibba L. and Valisneria spiralis L.) were also found in the reservoir littoral region (Bueno \& Bicudo 2006). The extent of the area covered by the charophyte at the different sites varied within each one and among them depending on the climatic season of year. Samplings were performed monthly from October 1996 to October 1997 in three fixed littoral stations (table 1). Total of 216 sample units were obtained.

Air temperature and rain precipitation information was provided by the Meteorological Station "Alexander Postoiev" of the Centro de Ciência e Tecnologia of the Universidade de São Paulo located ca. $1.5 \mathrm{~km}$ from the Ninféias Pond.

Water samples for physical and chemical variable determination were gathered only at the subsurface $( \pm 30 \mathrm{~cm}$ below surface) of reservoir. Bueno \& Bicudo (2006) summarizes the environmental variables measured for each sampling station at the Ninféias pond and their respective analytic methods.

Table 1. Monthly average values of the abiotic variables presently studied: accumulated rain precipitation (Prec.), wind speed (Wind), water temperature (Twater), air temperature (TAir), hydrogenionic potential (pH), conductivity (Cond.), ions bicarbonate $\left(\mathrm{HCO}_{3}\right)$, dissolved oxygen $\left(\mathrm{O}_{2}\right)$, free carbon dioxide (Free $\left.\mathrm{CO}_{2}\right)$, total phosphorus (TP), turbidity (Turb.) and dissolved inorganic nitrogen $(\mathrm{DIN})(\mathrm{Oct} / 96=$ October/1996; Nov $=$ November/1996; Dec $=$ December/1996; Jan/97 = January/1997; Feb = February/1997; Mar = March/1997; Apr = April/1997; May = May/1997; Jun = June/1997; Jul = July/ 1997; Aug $=$ August/1997; Sept $=$ September/1997 and Oct/97 = October/1997).

\begin{tabular}{lrcccccccccrr}
\hline Month & $\begin{array}{r}\text { Prec. } \\
(\mathrm{mm})\end{array}$ & $\begin{array}{c}\text { Wind } \\
\mathrm{m} \mathrm{h}^{-1}\end{array}$ & $\begin{array}{c}\text { Twater } \\
\left({ }^{\circ} \mathrm{C}\right)\end{array}$ & $\begin{array}{l}\text { TAir } \\
\left({ }^{\circ} \mathrm{C}\right)\end{array}$ & $\begin{array}{c}\mathrm{pH} \\
(\mathrm{pH})\end{array}$ & $\begin{array}{c}\text { Cond. } \\
\left(\mu \mathrm{cm}^{-1}\right)\end{array}$ & $\begin{array}{c}\mathrm{HCO}_{3} \\
\left(\mathrm{mg} \mathrm{L}^{-1}\right)\end{array}$ & $\begin{array}{c}\mathrm{O}_{2} \\
\left(\mathrm{mg} \mathrm{L}^{-1}\right)\end{array}$ & $\begin{array}{c}\text { Free } \mathrm{CO}_{2} \\
\left(\mathrm{mg} \mathrm{L}^{-1}\right)\end{array}$ & $\begin{array}{r}\mathrm{TP} \\
\left.(\mu \mathrm{g} \mathrm{L})^{-1}\right)\end{array}$ & $\begin{array}{r}\text { Turb. } \\
(\mathrm{NTU})\end{array}$ & $\begin{array}{r}\text { DIN } \\
\left(\mu \mathrm{g} \mathrm{L}^{-1}\right)\end{array}$ \\
\hline Oct/96 & 158.0 & 6.2 & 17.5 & 19.2 & 6.32 & 55.8 & 13.20 & 4.1 & 11.0 & 7.14 & 5.93 & 50.00 \\
Nov & 86.0 & 6.4 & 21.5 & 19.7 & 6.25 & 49.8 & 12.47 & 4.3 & 11.0 & 10.60 & 4.35 & 62.00 \\
Dec & 386.0 & 6.2 & 20.8 & 22.1 & 6.21 & 51.8 & 14.42 & 3.6 & 14.6 & 8.20 & 5.50 & 26.87 \\
Jan/97 & 341.0 & 6.0 & 23.0 & 22.1 & 6.11 & 59.5 & 13.13 & 3.3 & 15.8 & 5.90 & 5.21 & 91.00 \\
Feb & 108.0 & 5.7 & 20.0 & 22.6 & 5.88 & 64.6 & 9.70 & 3.8 & 15.6 & 5.20 & 15.00 & 313.40 \\
Mar & 67.0 & 5.3 & 21.1 & 20.8 & 6.11 & 56.8 & 9.85 & 3.7 & 12.4 & 7.30 & 10.10 & 129.60 \\
Apr & 47.0 & 5.3 & 21.1 & 19.4 & 6.50 & 55.0 & 10.95 & 4.5 & 15.9 & 8.20 & 5.40 & 115.20 \\
May & 80.0 & 5.3 & 19.6 & 17.2 & 6.02 & 56.2 & 13.11 & 3.7 & 22.4 & 6.80 & 4.76 & 97.00 \\
Jun & 108.0 & 6.5 & 13.4 & 15.9 & 6.19 & 54.4 & 11.73 & 5.4 & 14.0 & 4.50 & 5.18 & 106.30 \\
Jul & 9.0 & 4.7 & 17.1 & 17.1 & 6.22 & 48.0 & 10.00 & 5.7 & 10.6 & 4.80 & 5.15 & 83.30 \\
Aug & 38.0 & 4.8 & 18.1 & 17.1 & 6.36 & 52.1 & 13.36 & 6.1 & 10.3 & 3.30 & 5.15 & 101.20 \\
Sept & 130.0 & 5.6 & 18.1 & 18.4 & 6.34 & 48.4 & 12.68 & 6.5 & 9.9 & 2.40 & 5.20 & 48.40 \\
Oct/97 & 126.0 & 7.0 & 22.0 & 19.6 & 6.14 & 47.1 & 11.63 & 4.3 & 13.7 & 4.50 & 14.10 & 50.90 \\
\hline
\end{tabular}


Charophyte biomass was measured monthly using a PVC $25 \mathrm{~cm}^{2}$ square frame thrown at hazard to define the portion of the charophyte stand to be collected (Westlake 1965, 1971). Within the frame, a $5 \mathrm{~cm}$ diameter (area $19.7 \mathrm{~cm}^{2}$ ) PVC tube was used to collect the alga and sediments $(5 \mathrm{~cm}$ deep layer). For biomass determination, material was dried in a forced air circulation drier at $70{ }^{\circ} \mathrm{C}$ until constant weight (Hunter 1976). The aboveground biomass was calculated as dry weight per bottom surface unit. Algal total organic carbon was measured from the organic matter percentage of the plant material using Westlake (1963) and Wetzel (2001) coefficients. Organic C content is estimated to be $47 \%$ of the total organic matter after 1 hour incineration at $550{ }^{\circ} \mathrm{C}$. For total phosphorus determination, method in Andersen (1976) was used. For carbon concentration determination, aliquots between 0.03 and $0.97 \mathrm{~g}$ of dry and grounded plants were incinerated for 1 hour at $550{ }^{\circ} \mathrm{C}$. Inorganic dissolved phosphate $\left(\mathrm{P}^{-} \mathrm{PO}_{4}^{-3} \mu \mathrm{g} \mathrm{L}^{-1}\right.$ ) was measured according to Strickland \& Parsons (1960).

Variation coefficient (VC) was calculated according to Vieira (2006). Space and time ordination of samples was performed by applying the Principal Component Analysis (PCA) to the abiotic data, to a covariance matrix with data transformed by ranging. Average was used for central tendency measurement and standard deviation and variation coefficient for dispersion measurement during data descriptive analyses. Sample ordination in time and space was accomplished by PCA covariance matrix for PC-ORD program, version 3.11 for Windows according to McCune $\&$ Mefford (1997). Data were standardized by ranging using FITOPAC program (Shepherd 1996).

\section{Results}

There was little variation of air and water temperature during the study period (table 1), the lowest values (15.9$20.8^{\circ} \mathrm{C}$ ) occurring, as expected, during the dry period (October-November 1996 and March-October 1997) and the highest ones $\left(22.1-22.6^{\circ} \mathrm{C}\right)$ during the rainy period (December 1996-February 1997). In addition, as expected, water temperature generally followed air temperature.

Lowest $\mathrm{pH}$ value was measured during the rainy period (5.88 in February 1997). Turbidity highest values were observed in February (15.00 NTU), March (10.10 NTU) and October 1997 (14.10 NTU).

Charophyte biomass values in terms of dry weight varied from 65 to $300 \mathrm{~g} \mathrm{DW} \mathrm{m}^{-2}$ (VC 13.15-67.63\%) and ash values from 31 to $233 \mathrm{~g} \mathrm{~m}^{-2}$ (VC 7-120.87\%). Regarding the alga organic fractions, ash free dry weight (AFDW) varied between 30 and $130 \mathrm{~g} \mathrm{~m}^{-2}$ (VC 23.33$12 \%)$. During nearly the entire study period, AFDW was higher than the inorganic (ash) fraction, except for October 1996 and February and April 1997 (table 2). Total organic carbon values varied from 139 to $353 \mathrm{mg} \mathrm{g}^{-1}$ (VC 23-90.25\%). Charophyte biomass total phosphorus highest average value $\left(225 \mathrm{mg} \mathrm{m}^{-2}\right)$ was detected in November 1996, whereas the lowest value $\left(33.8 \mathrm{mg} \mathrm{m}^{-2}\right)$ was found in April 1997 (VC 30.2-53.43 \%). Sediment phosphorus varied from 3.3 to $46.2 \mathrm{mg} \mathrm{m}^{-2}$ (VC 00-00 \%) (table 2).

Table 2. Average values for the alga variables in the present study $(\mathrm{Dw}=$ dry weight; $\mathrm{Ash}=\mathrm{ash}$; AFDW $=$ ash free dry weight TC $=$ total organic carbon; Pmacroalgae $=$ total phosphorus of charophytes; Psediment $=$ total sediment phosphorus; Oct/96 = October/1996; Nov = November/1996; Dec = December/1996; Jan/97 = January/1997; Feb = February/1997; Mar = March/1997; Apr = April/1997; May = May/1997; Jun = June/1997; Jul = July/1997; Aug = August/1997 Sept $=$ September/ 1997 and Oct/97 = October/1997).

\begin{tabular}{lcrrcrc}
\hline Month & $\begin{array}{c}\text { Dw } \\
\left(\mathrm{g} \mathrm{m}^{-2}\right)\end{array}$ & $\begin{array}{c}\text { AFDW } \\
\left(\mathrm{g} \mathrm{m}^{-2}\right)\end{array}$ & $\begin{array}{c}\text { Ash } \\
\left(\mathrm{g} \mathrm{m}^{-2}\right)\end{array}$ & $\begin{array}{c}\text { TC } \\
\left(\mathrm{mg} \mathrm{m}^{-2}\right)\end{array}$ & $\begin{array}{c}\text { Pmacroalgae } \\
\left(\mathrm{mg} \mathrm{m}^{-2}\right)\end{array}$ & $\begin{array}{c}\text { Psediment } \\
\left(\mathrm{mg} \mathrm{m}^{-2}\right)\end{array}$ \\
\hline Oct/96 & 193.0 & 91.0 & 102.0 & 287.0 & 177.5 & 33.1 \\
Nov & 300.0 & 233.0 & 68.0 & 353.0 & 225.2 & 15.6 \\
Dec & 192.0 & 109.0 & 58.0 & 271.0 & 51.0 & 13.8 \\
Jan/97 & 286.0 & 183.0 & 103.0 & 343.0 & 203.7 & 37.0 \\
Feb & 113.0 & 31.0 & 83.0 & 139.0 & 38.9 & 46.2 \\
Mar & 200.0 & 145.0 & 56.0 & 327.0 & 81.3 & 41.5 \\
Apr & 169.0 & 78.0 & 90.0 & 224.0 & 33.8 & 3.3 \\
May & 140.0 & 77.0 & 61.0 & 254.0 & 35.7 & 6.3 \\
Jun & 191.0 & 97.0 & 94.0 & 252.0 & 23.8 & 8.2 \\
Jul & 65.0 & 35.0 & 30.0 & 262.0 & 85.0 & 37.9 \\
Aug & 80.0 & 49.0 & 31.0 & 264.0 & 97.8 & 37.7 \\
Sept & 217.0 & 130.0 & 87.0 & 283.0 & 53.8 & 19.6 \\
Oct & 108.0 & 55.0 & 52.0 & 254.0 & 82.3 & 27.3 \\
\hline
\end{tabular}


Principal Component Analysis summarizes 58\% of data variation in the two first axes (table 3, figure 1). Component $1(37 \%)$ indicated a tendency towards

Table 3. Pearson correlation coefficients among water physical and chemical characteristics, charophyte biological variables, and the two first ordination axes using PCA for the study period $(n=65)$.

\begin{tabular}{lccc}
\hline \multirow{2}{*}{ Variable } & Abbreviation & \multicolumn{2}{c}{$\begin{array}{c}\text { Principal } \\
\text { component }\end{array}$} \\
\cline { 2 - 4 } & & Axis 1 & Axis 2 \\
\hline Charopyte dry weight & $\mathrm{Dw}$ & -0.651 & -0.489 \\
$\mathrm{pH}$ & $\mathrm{pH}$ & -0.635 & -0.341 \\
$\mathrm{HCO}_{3}$ & $\mathrm{HCO}_{3}$ & -0.733 & -0.103 \\
Turbidity & $\mathrm{TUR}$ & -0.770 & -0.312 \\
Electric conductivity & $\mathrm{COND}$ & -0.483 & -0.591 \\
Dissolved inorganic & DIN & -0.849 & -0.223 \\
nitrogen & & & \\
Charophyte total & Pmacroalgae & -0.641 & -0.594 \\
phosphorus & & & \\
Sediment total & Psediment & -0.311 & -0.419 \\
phosphorus & & & \\
Water total phosphorus & TP & -0.335 & -0.572 \\
Carbon concentration & Tcarbon & -0.837 & -0.264 \\
Water temperature & Twater & -0.112 & -0.755 \\
\hline & & &
\end{tabular}

grouping abiotic and algal chemical characteristics in relation to fall and winter months (April-July) at the positive side of axis 1 , positively associated with the highest values of DIN ( $r=0.849)$ and turbidity $(r=0.770)$, and negatively associated with carbon $(r=-0.837)$ and dry weight ( $r=-0.651)$ values, evidencing the dry period.

Distribution of sampling units on axis 2 grouped summer months (February and March) which were positively associated with water temperature $(r=0.755)$ and water phosphorus $(r=0.572)$, charophyte phosphorus $(r=0.594)$ and conductivity $(r=0.591)$, evidencing the beginning of the rainy period favorable to the algal growth.

\section{Discussion}

In several lakes, Characeae occupy significant areas of their littoral, where they play a very important limnological role (Hutchinson 1975). Importance of Characeae in lakes littoral region is directly related to the amount of submerged biomass, their spatial structure and their association with other submerged and emerged plants besides their use as shelter for aquatic invertebrates (Pereira-Ramos 1981).

Regarding temporal variation, highest average values of total biomass were detected during the rainy period (113-300 $\left.\mathrm{g} \mathrm{m}^{-2} \mathrm{DW}\right)$ and lowest values $\left(65-217 \mathrm{~g} \mathrm{~m}^{-2} \mathrm{DW}\right)$ during the dry period. Algal biomass values 5-fold greater

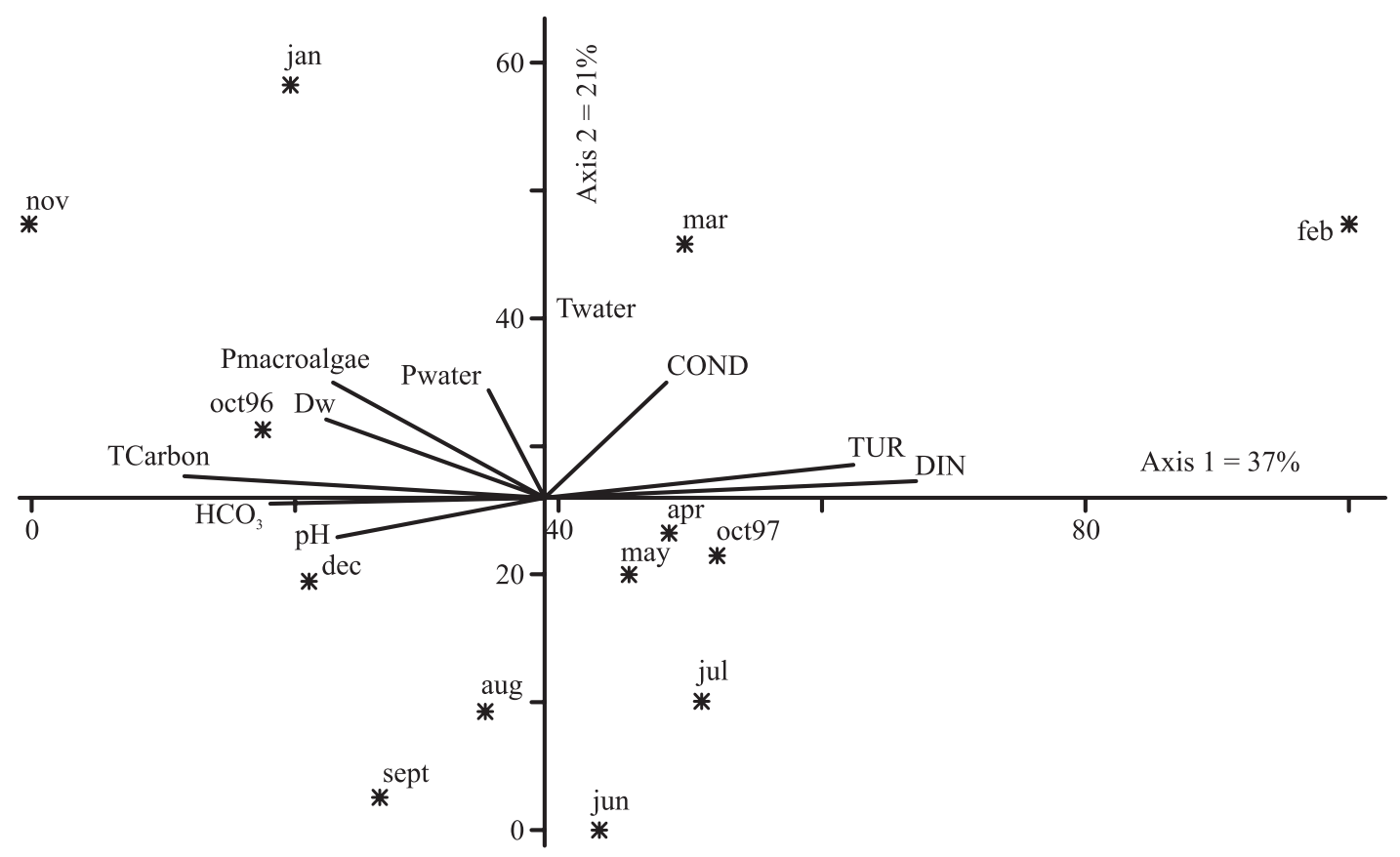

Figure 1. Ordination of physical and chemical characteristics of the Ninféias Pond littoral region water, using principal components multivariate analysis (axes 1 and 2) and the 4 samplings stations for the period October 1996 to October 1997. 
during the rainy period than in the dry one were likely due to lower water temperature values measured during the latter period, which did not favor algal growth during that period of the year. Conversely, however, highest nutrient availability associated to the highest temperatures during the rainy period most probably favored growth of Nitella furcata subsp. mucronata var. mucronata $\mathrm{f}$. oligospira in the Ninféias Pond. Carneiro et al. (1994) reported similar condition for the Piratininga lagoon in the state of Rio de Janeiro, Palma-Silva et al. (2002a) for an unnamed coastal lagoon also in the state of Rio de Janeiro, and Fernandez-Aláez et al. (2002) for shallow lakes in the northwest of Spain. Vieira Junior \& Necchi Junior (2002) observed an opposite tendency in the lotic environment, since depth played a negative influence on the biomass (in terms of percentage cover of Chara guairensis). The enormous amount of rain during the winter determined the increase of the system depth and a decrease of the charophyte population abundance.

Lowest biomass values of Nitella furcata subsp. mucronata var. mucronata f. oligospira observed in July 1997 most probably reflected the adverse prevailing conditions during the dry period. Palma-Silva's et al. (2004) charophyte biomass values between 172 and $510 \mathrm{~g} \mathrm{~m}^{-2} \mathrm{DW}$ and those of Kufel \& Kufel's (2002) between 42 and $500 \mathrm{~g} \mathrm{~m}^{-2} \mathrm{DW}$ were ascribed to specific characteristics as their high capacity for nutrient storage in their biomass, mainly $\mathrm{N}$ and $\mathrm{P}$, associated to the low turbidity and high water transparency values, besides the positive correlation between $\mathrm{N}$ and $\mathrm{P}$ concentration in the charophyte biomass that indicated metabolic activity (protein synthesis) due to nutrient availability in the water column and environmental conditions (light, alkalinity, $\mathrm{Ca}, \mathrm{N}$ and $\mathrm{P}$ concentration). In temperate regions, aquatic macrophytes present sharp annual variation, with a typical growth period of their aerial biomass during the spring and summer and another one well marked by subterranean biomass accumulation and detritus represented by fall and winter (Esteves \& Camargo 1986). Determinant factors for aquatic macrophytes biomass seasonality in the tropics are, however, dry and rainy periods (Esteves 1988).

Biomass calculated in terms of dry weight and ash free dry weight showed the same seasonal variation pattern during the entire study period. Schloesser et al. (1985) and Kairesalo et al. (1992) detected same seasonal behavior for the Detroit river system between lakes Huron, Erie and Thingvallavatn in the north temperate zone of the globe.

Inorganic fraction (ashes) depends, according to Wetzel (1965), on the species, the environmental conditions and the $\mathrm{CaCO}_{3}$ thallus impregnation. The latter fraction is usually smaller than that of dry weight and may vary between 15 and $25 \%$ of the plant dry weight (Westlake 1965). In the case of calcareous macroalgae such as the Characeae, ash contents may reach up to $70 \%$ of their dry weight. Nitella furcata subsp. mucronata var. mucronata f. oligospira's lowest values were observed during the dry period and the highest ones in the rainy period. During almost the entire study period, AFDW values were higher than those of $\mathrm{C}$, except for October 1996 and February and April 1997.

Carbon concentration performed $47 \%$ of total organic matter, a percentage usually present in aquatic macrophytes in general. Consequently, organic $\mathrm{C}$ contents seasonal variation followed the increase of aquatic charophyte biomass values registered in terms of dry weight and AFDW. As an average, such values were higher during the rainy period, when growth and biomass accumulation were observed due to the increase of water temperature and greater nutrient availability in the reservoir. Thus, charophyte organic $\mathrm{C}$ values were inversely proportional to those of ash.

Nitella furcata subsp. mucronata var. mucronata f. oligospira dry weight:total organic $\mathrm{C}$ ratio values did not indicate a marked seasonal variation, their average highest value (0.84:1) being registered in November 1996, during the rainy period, and the average lowest values (0.20:1) in July 1997, during the dry period. Low C contents in Nitella species is due to the low carbohydrate values in their cells (Westlake 1965).

Regarding biomass total phosphorus concentration, values varied from 0.26 to $1.60 \mathrm{mg} \mathrm{g}^{-1} \mathrm{DW}$. Blindow (1992) registered $0.63-0.8 \mathrm{mg} \mathrm{g}^{-1} \mathrm{DW}$ for Chara tomentosa in Swedish lakes, whereas Palma-Silva et al. (2004) reported $5-0.85 \mathrm{mg} \mathrm{g}^{-1} \mathrm{DW}$ for charophytes in the Imboassica lagoon, state of Rio de Janeiro, Brazil.

In what respects total phosphorus temporal dynamics in the distinct water compartments (Nitella furcata subsp. mucronata var. mucronata f. oligospira plants and reservoir sediments), results of present study suggest existence of two distinct periods regarding total phosphorus values, i.e., a period of high TP values in the charophyte and littoral water $($ rainy period $=$ plant growth period $)$ and another one of low values in the charophyte, water and sediments (dry period). According to Luciano \& Henry (1998), system behavior (sediments, water, and aquatic macrophytes) is strongly related to the dry season, when a decrease in the nutrient availability to the water column occurs. Similar behavior was verified by Da-Silva \& Esteves (1993) in the Barão de Melgaço Pantanal, state of Mato Grosso.

Palma-Silva et al. (2004) detected positive correlation between $\mathrm{N}$ and $\mathrm{P}$ concentrations in the charophyte and 
the water column, a condition that was also detected by Garten (1976) for charophytes and some other non-vascular plants.

As an average, Characeae TP values were up to 4 times greater than that in the sediments and about 50 times than that of the water.

Blindow (1992) measured TP values 3 times greater in Chara tomentosa and Nitellopsis obtusa than in the water (values measured at the system subsurface) and 9 times greater than those of the sediment $(0-5 \mathrm{~cm})$. Opposite situation was verified by Kairesalo et al. (1992) that observed that Nitella sp. biomass presented amounts of $\mathrm{N}$ and $\mathrm{P}$ two times lower than those of the lake sediments. Palma-Silva et al. (2002a) obtained a positive correlation between $\mathrm{P}$ concentration in the charophyte biomass and that of the water column, suggesting that nutrient concentration in Characeae species at the Imboassica lagoon, Rio de Janeiro State, is significantly related to the environmental conditions.

From the PCA analysis prepared for the water physical and chemical variables and the charophyte chemical ones, separation of sampling stations at the Ninféias Pond in terms of end of the rainy period and beginning of the dry one was verified. Based on the fact that highest dry weight and organic $\mathrm{C}$ values were registered from October to December 1996 and in January and March 1997 (rainy period), a period that coincided with the plant growth, PCA clearly demonstrated that certain charophyte morphological characteristics showed seasonality.

\section{References}

ANDERSEN, J.M. 1976. An ignition method for determination on total phosphorus in lake sediments. Water Research 10:329-331.

BICUDO, C.E.M., CARMO, C.F., BICUDO, D.C., HENRY, R., PIÃO, A.C.S., SANTOS, C.M.S. \& LOPES, M.R. M. 2002. Morfologia e morfometria de três reservatórios do PEFI. In Parque Estadual das Fontes do Ipiranga (PEFI): unidade de conservação que resiste à urbanização de São Paulo (D.C. Bicudo, M.C. Forti \& C.E.M. Bicudo, orgs.). Secretaria do Meio Ambiente do Estado de São Paulo, São Paulo, p.143-160.

BLINDOW, I. 1992. Long and short-term dynamics of submerged macrophytes in two shallow eutrophic lakes. Freshwater Biology 28:15-27.

BUENO, N.C. \& BICUDO, C.E.M. 2006. Temporal variation of Nitella furcata subsp. mucronata var. mucronata $\mathrm{f}$. oligospira (Charophyceae) in the Ninféias pond, São Paulo State, southeast Brazil. Acta Botanica Brasilica 20:1-11.
CARNEIRO, M.E.R., AZEVEDO, C., RAMALHO, N.M. \& KNOPPERS, B. 1994. A biomassa de Chara hornemannii em relação ao comportamento físico-químico da lagoa de Piratininga (RJ). Anais da Academia Brasileira de Ciências 66:213-222.

CONTI, J.B. \& FURLAN, S.A. 2003. Geoecologia: o clima, os solos e a biota. In Geografia do Brasil. (J.L. Ross, org.). Editora da Universidade de São Paulo, São Paulo, p.67-207.

DA-SILVA, C.J. \& ESTEVES, F.A. 1993. Biomass of three macrophytes in the Pantanal of the Mato Grosso, Brazil. International Journal of Ecology and Environmental Sciences 19:11-23.

ESTEVES, F.A. 1988. Considerações sobre a aplicação da tipologia de lagos temperados a lagos tropicais. Acta Limnologica Brasiliensia 2:3-28.

ESTEVES, F.A. \& CAMARGO, A.F.M. 1986. Sobre o papel das macrófitas aquáticas na estocagem e ciclagem de nutrientes. Acta Limnologica Brasiliensia 1:273-298.

FERNÁNDEZ-ALÁEZ, M., FERNÁNDEZ-ALÁEZ, C. \& RODRÍGUEZ, S. 2002. Seasonal changes in biomass of charophytes in shallow lakes in the northwest of Spain. Aquatic Botany 72:335-348.

GARTEN, C.T. 1976. Correlations between concentrations of elements in plants. Nature 261:686-688.

HUNTER, R.D. 1976. Changes in carbon and nitrogen content during decomposition of three macrophytes in freshwater and marine environments. Hydrobiologia 51:119-128.

HUTCHINSON, G.E. 1975. A treatise on limnology: limnological botany. John Willey \& Sons, New York.

KAIRESALO, T., JÓNASSON, G.S., GUNNARSSON, K., LINDEGAARD, C. \& JÓNASSON, P.M. 1992. Metabolism and community dynamics within Nitella opaca (Charophyceae) beds in Thingvallavatn. Oikos 64:241-256.

KUFEL, L. \& KUFEL, I. 2002. Chara beds acting as nutrient sinks in shallow lakes: a review. Aquatic Botany 72: 249-260.

LUCIANO, S.C. \& HENRY, R. 1998. Biomass of Eichhornia azurea Kunth. and Brachiaria arrecta Stent. in lower Taquari river, Jurumirim Reservoir, São Paulo, Brazil. Verhandlungen der Internationale Vereinigung für Theoretische und Angewandte Limnologie 26:1857-1861.

McCUNE, B. \& MEFFORD, M.J. 1997. PC-ORD. Multivariate analysis of ecological data, version 3.0. MjM Software Design, Oregon.

PALMA-SILVA, C., ALBERTONI, E.F. \& ESTEVES, F.A. 2002a. Clear water associated with biomass and nutrient variation during the growth of a Charophyte stand after a drawdown, in a tropical coastal lagoon. Hydrobiologia 482:79-87.

PALMA-SILVA, C., ALBERTONI, E.F. \& ESTEVES, F.A. $2002 \mathrm{~b}$. The role of charophytes primary production in a coastal lagoon subjected to human impacts (RJ, Brazil). Acta Limnologica Brasiliensia 14:59-69. 
PALMA-SILVA, C., ALBERTONI, E.F. \& ESTEVES, F.A. 2004. Charophytes as a nutrient and energy reservoir in a tropical coastal lagoon impacted by humans (RJ, Brazil). Brazilian Journal of Biology 64:479-487.

PEREIRA-RAMOS, E. 1981. The ecological role of Characeae in the lake litoral. Ekologia Polska 29:167-209.

SCHLOESSER, D.W., EDSALL, T.A. \& MANNY, B.A. 1985. Growth of submerged macrophyte communities in the St. Clair-Detroit river system between Lake Huron and Lake Erie. Canadian Journal of Botany 63:1061-1065.

SHEPHERD, G.J. 1996. FITOPAC 1: manual do usuário. Universidade Estadual de Campinas, Campinas.

STRICKLAND, J.D. \& PARSONS, T.R. 1960. A manual of sea water analysis. Bulletin of the Fisheries Research Board of Canada 125:1-185.

VIEIRA, S. 2006. Análise de variância (ANOVA). Editora Atlas S.A., São Paulo.

VIEIRA JUNIOR, J. \& NECCHI JUNIOR, O. 2002. Microhabitat and plant structure of Characeae (Chlorophyta) populations in streams from São Paulo State, southeastern Brazil. Cryptogamie, Algologie 23:51-63.

VIEIRA JUNIOR, J. \& NECCHI JUNIOR, O. 2003. Photosynthetic characteristic of charophytes from tropical lotic ecossystems. Phycological Research 51: 51-60.
VIEIRA JUNIOR, J., NECCHI JUNIOR, O., BRANCO, C. C.Z. \& BRANCO, L.H.Z. 2002. Characeae (Chlorophyta) de ecossistemas lóticos do estado de São Paulo, Brasil, 1: gênero Nitella. Hoehnea 29:249-266.

VIEIRA JUNIOR, J., NECCHI JUNIOR, O., BRANCO, C. C.Z. \& BRANCO, L.H.Z. 2003. Characeae (Chlorophyta) de ecossistemas lóticos do estado de São Paulo, Brasil, 2: gênero Chara e distribuição geográfica. Hoehnea 30:53-70.

WESTLAKE, D.F. 1963. Comparations of plant productivity. Biological Reviews 38:385-425.

WESTLAKE, D.F. 1965. Some basic data for investigations of the productivity of aquatic macrophytes. Memorie dell'Istituto Italiano di Idrobiologia Dottore Marco de Marchi 18:229-248.

WESTLAKE, D.F. 1971. Macrophytes. In A manual of methods for measuring primary production in aquatic environments (R.A. Vollenveider, org.). Blackwell Scientific Publication, Oxford, p.25-32. (I.B.P. Handbook $\mathrm{n} \times$ ㅇ) 12).

WETZEL, R.G. 1965. Techniques and problems of primary productivity measurements in higher aquatic plants and periphyton. Memorie dell'Istituto Italiano di Idrobiologia Dottore Marco de Marchi 18:249-267.

WETZEL, R.G. 2001. Limnology: lake and river ecosystems. Academic Press, San Diego. 